\title{
Introduction of Sustainable Development toward Early Childhood Education in Indonesia
}

\author{
Bustomi Arifin $^{\text {a }}$, Aan Listiana ${ }^{\text {a }}$, Andini Dwi Arumsari ${ }^{\text {b }}$, Arasy Alimudin ${ }^{\text {b }}$, Sri Wiwoho \\ Widjanarkob

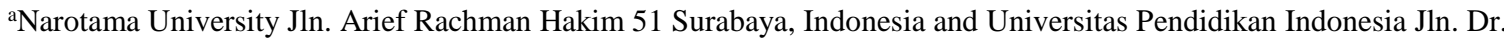 \\ Setiabudhi N0. 229 Bandung, Indonesia \\ bNarotama University Jln. Arief Rachman Hakim 51 Surabaya, Indonesia.
}

Corresponding e-mail: Bustomi.Arifin@narotama.ac.id

\begin{abstract}
Sustainable development nowadays becomes trending discussion among scholars in numerous areas including educational discourse. It becomes major discussion since scholars believed that sustainable development education possesses capacity to share concern for future of the planet and local communities all over the world. Numerous countries through their education ministry encourage introduction of sustainable development into all educational areas. The present study aims to seek an effective strategy to introduce sustainable development in Indonesia. The present study uses descriptive analysis in portraying the role of early childhood education to establish sustainable society coupled with depicting an effective strategy in introducing sustainable development to early childhood children in Indonesia. The present study concludes that early childhood educational system in Indonesia needs to be revised or enhanced in order to achieve the sustainable development goals that are declared by Indonesian government.
\end{abstract}

Keywords: sustainable development, early childhood education, sustainable development goals

\section{INTRODUCTION}

Sustainable development nowadays becomes trademark in numerous areas including educational discourse worldwide. Huckle argues that sustainable development is a concept which refers to the way humans should behave on earth. It covers the development of economic welfare coupled with social justice for all humankind now and in the future within ecological limits of our earth (2006). As a matter of fact, it becomes phenomena since it is believed that sustainable development education has capacity to share concern for future of the planet and local communities all over the world (Jucker and Reiner Mathar, 2015). However, it is not easy to introduce sustainable development education into educational activities since sustainable issue lacks of shared meaning and stemming concerning future problems that will be faced the planet. Various countries nowadays have already concern about education for sustainable development. Those countries through their education ministry impose and implement regulation concerning education for sustainable development all educational areas (early childhood education, elementary, junior high school, senior high school and university). Furthermore, the United Nations also encourage those countries to seek ways in order to introduce education for sustainable development into school. It is presumed that children, older students and adults hold huge potential to be educated formally to act now in the interests of a sustainable future and to act internationally (ibid). Indonesia as developing country also concerns about education for sustainable development since Indonesian president at this time Joko Widodo establishes Joint Committee to implement Indonesian Sustainable Development Goals that is proclaimed by Indonesian government in 2015 (Tempo, 2015). So far, implementation of education for sustainable development in Indonesia needs to be strengthened in order to achieve the sustainable development goals that are declared. An alternative that can be taken by Indonesian government to strengthen public concern regarding sustainable development is through early childhood education.

The present study aims to elaborate an effective strategy in introducing sustainable 
development to early childhood children in Indonesia. Indonesian Ministry of Education emphasizes the output of early childhood education into various values of basic competencies which are spiritual, social, knowledge, and skills. It can be seen from Indonesian Education ministry decree about early childhood education No. 146, 2014 (Indonesian Education ministry, 2014). Based on this decree, it can be seen that sustainable development is not priority values for early childhood education. Moreover, the present study aims to picture that introduction of sustainable development education for early childhood will bring positive impacts coupled with encourage them to be involved in sustainable society. Scholars believe that early childhood education should play an essential role in building a sustainable society since it can be seen as a first stage in fostering a sustainable lifestyle, respecting others coupled with developing a non-ethnocentric perception (Qemuge \& Inner cited in Samuelsson and Yoshie, 2008).

Early childhood education is the foundation for the growth and future development of all children. It is generally accepted as the education that given to under 6 years old children. This kind of education precedes the beginning of formal primary school or before the age in which children are commonly expected to attend schools (Maduewesi and Augosiobo, 2005). Therefore, introducing and including education for sustainable development into early childhood education in Indonesia can be seen as an effective strategy for our children to become the part of sustainable society in the future. In order to become a part of sustainable society, children education, and in particular early childhood children, is an essential tool for individuals as well as for public. As the growing generation, early childhood children will have increased demand for citizens who have essential knowledge and are capable in making decisions coupled with choices that will have an impact on the environment (Roth and McGinn, 1998). The present study does not aim to judge that early childhood educational system in Indonesia is wrong or not good but rather to demonstrate that sustainable development goals that is proclaimed by Indonesian government can be achieved handily by including sustainable development as basic competence values of early childhood education.

\section{METHODOLOGY}

The present study uses descriptive analysis in portraying the role of early childhood education in establishing a sustainable society and depicting an effective strategy in introducing sustainable development to early childhood children in Indonesia. First stage of the present study will be examining early childhood educational system in Indonesia. The next stage will be elaborating and discussing the role of encouraging sustainable development to early childhood children. Introduction of sustainable development toward early childhood education in Indonesia will be the last discussion of the present study. Last but not the least will be the conclusion section in the present study. All methods mentioned above will be conducted through literature study in order to get scientific result for the issue mentioned above.

\section{DESCRIPTION OF EARLY CHILDHOOD LEARNING METHOD IN INDONESIA}

Education for sustainable development in numerous develop countries become an important issue therefore those countries introduce sustainable development toward early childhood children through education. Those countries believe that education, including informal education, public awareness and training are various alternatives for promoting education for sustainable development and improving the capacity of people to address environment and development issues. While basic education, including early childhood education, provide the underpinning for any environmental and development education, the latter need to be incorporated as an essential part of education (Scott, 2013). Meanwhile, education for sustainable development is not included yet into early childhood education curriculum in Indonesia. It can be seen from the basic competencies that are emphasized by the Indonesian ministry of Education through its decree.

Educational method for early childhood in Indonesia is regulated in Indonesian Education ministry Decree No 146, 2014. This regulation describes that early childhood education is a development effort or stage in particular for early childhood children which aim to provide educational stimulus to maintain their developmental stage in entering primary education which is starting from $0-6$ years children (Indonesian Ministry of Education, 2014). Furthermore, the essence of early childhood education is an education before children entering primary education which can be done in various ways such as formal, non-formal and in-formal. Early childhood education in Indonesia emphasises physical development (harmonization of soft and hard motoric), intelligence (think, create, emotional intelligence, spiritual intelligence), socio emotional (attitude, behaviour and religion), language coupled with communication, and numerous things based on development stages of early childhood children (Jesica C, 2013). Moreover, the best approach in order to achieve above mentioned competencies for early childhood children is by learning while playing. It is believed that through playing early childhood children able to learn numerous things, recognizing rules and regulations, self-positioning, 
tolerance, socialization and other positive behaviours (Rachmawati \& Kurniati, 2011).

Reading, writing and arithmetic become phenomena in Indonesia nowadays since numerous early childhood school or kindergarten encourage early childhood student to develop their competence to read, write and count. This condition is stimulated by the requirement for 6 years children in registering for primary school, they shall be able to read, write and count. The present issue creates situation in which early childhood children are forced to study rather than enjoying their golden age stages to learn through playing. Scholars argue that reading, writing and counting will stimulate cognitive coupled with intellectual aspects meanwhile other aspects such as social emotion and arts are neglected (ibid). Based on descriptions mentioned above, it can be said that education for sustainable development is not main agenda for early childhood education.

\section{THE ROLE OF ENCOURAGING SUSTAINABLE DEVELOPMENT TO EARLY CHILDHOOD CHILDREN}

As afore mentioned in the previous section that it is not easy to make and encourage people to concern about sustainable development. Started from 2004, the United Nations held numerous international conferences to discuss promoters and barriers related to learn for sustainability. Moreover, those conferences were held since societies urgently require new pathway of education which able to prevent further degradation of our planet (Samuelsson and Yoshie Kaga, 2008). According to the result of $1^{\text {st }}$ international conferences established by the United Nations concerning sustainable development, it can be concluded that encouraging sustainable development into early childhood education program can be viewed as an effective strategy to increase people concern toward sustainable development. At the beginning this strategy is considered as unusual topic for the field of early childhood education coupled with numerous scholars in particular early childhood educators view sustainable development as discouraging, fearful, depressing and inappropriate for early childhood children (ibid). Scholars and early childhood educators question concerning sustainable development can be regarded as common question since those educators do not possess firm knowledge about sustainable development coupled with role of encouraging sustainable development to early childhood children.

As time passes, numerous scholars coupled with early childhood educators nowadays possess firm knowledge about sustainable development therefore those educators support the idea that sustainable development becomes agenda coupled with topic in early childhood education programmes. It becomes agenda since various scholars and educators believe that children, in particular early childhood children, have capacities to be active agents in contributing for sustainable development such as shaping environmental attitudes, knowledge and actions in the future. Furthermore, it also believes that early childhood period is the foundation or establishment stages of thinking, being, knowing, and acting as "hard net" relationship -with others within society and environment- (Chawla, 1998; Davis and Gibson, 2006; cited in Samuelsson and Yoshie Kaga, 2008). Besides, sustainable development education for early childhood children can be regarded as an appropriate strategy to ensure adequate care and development for all children which able to teach them kinds of knowledge, skills and values - such as empathy, sharing, respect for others, love for nature - that promote sustainability from a very early age (Kaga, Yoshie cited in Samuelsson and Yoshie Kaga, 2008 pp 53-56). Last but not the least, education for sustainable development should provide children, particularly early childhood children, knowledge, values, desire and skills to make decisions in maintaining a sustainable future. Children should also comprehend and realize that our dependency on the resources of nature will not last long therefore children also need to learn conflict-solving skills and improve their ability to seek new solutions, make responsible decisions and act upon them (Norddahl, K and Jonsdottir, S., 2001 cited in Samuelsson and Yoshie Kaga, 2008, pp. 73-77).

\section{INTRODUCTION OF SUSTAINABLE DEVELOPMENT TOWARD EARLY CHILDHOOD EDUCATION IN INDONESIA}

On Friday, September 29 2015, more than 150 countries leader around the globe including Indonesia gathered and formally adopted the Sustainable Development Goals (SDGs). This event is pioneered by the United Nations, in which it has agenda to achieve 17 goals and 169 targets cover areas such as poverty, public health, the environment, education and justice (the United Nations, 2015). It can be said that as an active part of the Sustainable Development Goals program, Indonesia needs to prepare numerous strategies in order to achieve 17 goals and 169 targets that are proclaimed. An alternative that can be adopted by Indonesian government is by introducing sustainable development toward early childhood education.

As afore mentioned, it can be seen that nowadays educational system for early childhood education in Indonesia emphasises basic competencies in regard to read, write and arithmetic for early childhood children. The present educational system needs to be enhanced in 
order to achieve the sustainable development goals. The sustainable goals will not be achieved if educational system for early childhood children is still emphasizing basic competencies in regard to read, write and arithmetic since this approach will stimulate cognitive coupled with intellectual aspects meanwhile other aspects such as social emotion and arts are neglected (Rachmawati \& Kurniati, 2011). Educational methods which can be adapted by Indonesian Ministry of Education concerning introduction of sustainable development toward early childhood education are: learning, experiencing and expressing. It does not mean that read, write and arithmetic is not a good educational system rather than to depict this system is not appropriate to achieve the sustainable development goals.

According to socio-cultural perspectives, children cannot be separated from the social and cultural process through which they growth, the values and goals which inform the ways children are treated coupled with understood (Woodhead, 2002 cited in Franklin et al, 2013). It means that development of early childhood children cannot be separated from their social and cultural process. In accordance to sustainable development based on perspective mentioned above, early childhood educational system in Indonesia also need to concern about the way how children learn through playing about current sustainable development issues based on social coupled with cultural process in Indonesia. Moreover, planned and well-prepared learning environments set by educators offer children opportunities for full, balanced development of their abilities including their ability to acknowledge sustainable development issues (ibid).

After learning the current sustainable development issues through their social and cultural process, educators shall provide method for early childhood children to experience what they have learnt about sustainable development. It is believed that learning opportunities derive through exploration, investigation, observation and reflection surround them (Franklin, et al, 2013). Furthermore, Didonet cited in Samuelsson and Yoshie Kaga (2008) argues that children are very sensitive to nature and its elements - animals, plants, flowers, the phenomena of fire, the land, wind, etc. In other words, it can be said that by experiencing sustainable development issues surround them hopefully they are able to possess knowledge, values, desire and skills to make decisions in maintain a sustainable future.

Last but not the least, early childhood educators also need to encourage children in expressing their ideas concerning sustainable development. Learning, experiencing coupled with respecting other people and cultures is an essential part in the education of sustainable development. It is also important for children to experience that their voices are heard and dealt in a respected way (Norddahl, K and Jonsdottir, S., 2001 cited in
Samuelsson and Yoshie Kaga, 2008, pp. 73-77). It can be said that by encouraging early childhood children to express their voice or idea, we as adult are helping children to become active citizens in contributing for a sustainable society. By expressing their voice or idea, we also provide children confidence since they need to be trusted and viewed as capable learners to give them opportunities to elaborate, examine, investigate, discuss, and form their own opinions on numerous sustainable development issues whether the problems are big or small (ibid).

\section{CONCLUSION}

Early childhood education is the foundation for the growth and future development of all children. It is generally accepted as the education that given to under six (6) years old children. Therefore introduction to education for sustainable development can be implemented or included within early childhood educational system. Education for sustainable development should give children, particularly early childhood children, knowledge, values, desire and skills in making decisions concerning a sustainable future.

In case of early childhood education system in Indonesia, the present study concludes that it needs to be revised or enhanced in order to achieve the sustainable development goals that are proclaimed by Indonesian government. It needs to be revised or enhanced since read, write and arithmetic as the basic competencies that are emphasized in the early childhood educational system can be regarded as inappropriate educational strategy to achieve the sustainable development goals. Appropriate educational strategies that can be implemented toward early childhood education to attain the sustainable development goals are: learning, experiencing and expressing. Learning enables children to acknowledge sustainable development issues through social and cultural process. Meanwhile, experiencing provides the essence of learning through exploration, investigation, observation and reflection surround them. Last but not the least, expressing provides children ability to be trusted and viewed as capable learners to give them opportunities to elaborate, examine, investigate, discuss, and form their own opinions on numerous sustainable development issues whether the problems are big or small. Introduction of sustainable development toward early childhood children does not mean to give children burden in solving the environmental problems for which adults are responsible, but rather to provide tools and methods which can be used in making decision and action for a sustainable future. 


\section{REFERENCES}

Chawla, L. 1998, Significant Life Experiences Revisited: A Review of Research on Sources of Environmental Sensitivity, Environmental Education Research, 4 (4), 369-383.

Davis, J.; Gibson, M., 2006, Embracing Complexity: Creating Cultural Change through Education for Sustainability, International Journal of Knowledge, Culture and Change Management, 6 (2), 92-102.

Franklin, Kimberly et al, (2013), ACDE's Accord on Early Learning and Early Childhood Education, Canada: Association of Canadian Deans of Education. Retrieved 30 August 2016 from: https://www.oise.utoronto.ca

Huckle, J., Education for Sustainable Development: Briefing Document, retrieved 26 August 2016 from:

http://www.ttrb.ac.uk/Browse2.aspx?anchorld=146 $33 \&$ selectedld $=14639$

Indonesian Ministry of Education Decree concerning Early Childhood Education No. 146, 2016, retrieved 26 August 2016 from: http://staff.unila.ac.id/ngadimunhd/files/2012/ 03/Permendikbud-No-146-2014.pdf

Jesica, C, (2013), Pendidikan Anak Usia Dini Berbasis Seni di Sewon Yogyakarta, Bachelor Thesis of Universitas Atmajaya Yogyakarta retrieved 28 August 2016 from: http://ejournal.uajy.ac.id/4228/3/2TA12922.pdf

Jucker Rolf \& Reiner Mathar, (2015), Schooling for Sustainable Development in Europe: Concepts, Policies, and Educational Experiences at the End of the UN Decade of Education for Sustainable Development, Switzerland: Springer International Publishing.
Norddahl, K and jonsdottir, S., 2001, Umhverfismennt i Leikskola [Environmental Education in Preschool], Athoth 1, tbl, 33, arg.

Qemuge, Siren \& Inner Mongolia cited in Samuelsson, Inggrid Pramling \& Yoshie Kaga, (2008), The Contribution of Early Childhood Education to a Sustainable Society, France: UNESCO.

Rachmawati, Yeni \& Euis Kurniati, (2011), Strategi Pengembangan Kreativitas pada Anak Usia Taman Kanak-kanak, Jakarta: Kencana Prenada Media Group.

Roth, M.,; McGinn, M.K., (1998), Knowing, Researching, and Reporting Science Education: Lesson from Science and Technology Studies, Journal of Research in Science Teaching, 35 (2), 213-235.

Samuelsson, Inggrid Pramling \& Yoshie Kaga, (2008), the Contribution of Early Childhood Education to a Sustainable Society, France: UNESCO.

Scott, W., (2013), Developing the Sustainable School: Thinking the Issues through the Curriculum Journal, 24(2), 181-205.

Sustainable Development Goals (SDG), Jokowi Gandeng Aktivis, Tempo 18 December 2015, Jakarta, retrieved 26 August 2016 from:

https://m.tempo.co/read/news/2015/12/18/0787290 48/sustainable-development-goals-sdgsjokowi-gandeng-aktivis

The United Nations, 2015, Sustainable Development Goals: 2015 is the Time for Global Action retrieved 30 August 2016, from: http://www.un.or.id/en/what-we-do/sdg

Woodhead, M., (2006), Changing Perspectives on Early Childhood: Theory, Research and Policy, Background Paper Prepared for the Education for All Global Monitoring Report 2007, Strong Foundations: Early Childhood Care and Education. 